\title{
Impact of climate variability on hydropower generation in an un-gauged catchment: Erathna run-of-the-river hydropower plant, Sri Lanka
}

\author{
Anushka Perera $^{1} \cdot$ Upaka Rathnayake ${ }^{2,3}$ (1)
}

Received: 2 July 2018 / Accepted: 7 March 2019 / Published online: 27 March 2019

(c) The Author(s) 2019

\begin{abstract}
Impact of climate change or climate variability on water resources is an exceedingly concerned issue. Hydropower development is one of the most affected industries due to the climatic variability. Therefore, this paper presents the promising results from a study of the impact of climate variability on hydropower generation of Erathna run-of-the-river (ROR) hydropower plant located in Rathnapura district, Sri Lanka. This study was based on surrounded rain gauges outside the catchment as Erathna catchment area is an un-gauged catchment. 30-year rainfall trend analysis from 1988 to 2017 was done using Mann-Kendall and Sen's slope estimator tests to predict the available trends. Pearson's correlation coefficient was used to investigate the relationship between rainfall and Erathna power generation. Results show negative trends for annual rainfalls in several rain gauges, while seasonal trend analyses support that observation. July is the most critical month for most of the rain gauges around the catchment. The results also show a good correlation between the rainfalls and power generation. Therefore, the results conclude the importance of rainfall trend analysis in un-gauged catchments and its forecasting capacity of water resources usage in hydropower development.
\end{abstract}

Keywords Climate variation $\cdot$ Erathna hydropower plant $\cdot$ Mann-Kendall test $\cdot$ Monthly rainfall $\cdot$ Trend analysis

\section{Introduction}

Energy is a key component in human lives and the world's economy, although it is considered one of the major causes for greenhouse gas (GHG) emissions and, consequently, the climate change (Edenhofer et al. 2011). Hence, attention has arisen over the impacts of climate change on physical and economic environments. Thus, researches have been carried out around the world to invent novel and advanced technologies to generate carbon-free electricity (Williams et al.

Upaka Rathnayake

upakasanjeewa@gmail.com; upaka.r@sliit.lk;

upaka.rathnayake@curtin.edu.au

Anushka Perera

anushkaminipro@gmail.com

Pahala Bomiriya, Kaduwela, Sri Lanka

2 Department of Civil Engineering, Faculty of Engineering, SLIIT, Malabe, Sri Lanka

3 School of Civil and Mechanical Engineering, Bentley Campus, Curtin University, Bentley, WA, Australia
2012). This has led to deployment of renewable resources for the power generation, and countries like Denmark, Ireland and Spain expect to yield more than half of their power generation requirement through renewable sources within next two decades (Smith 2018). Hydropower is used mainly as a dispatchable power generation for integrating renewable sources in electric grid and carbon reduction (Tarroja et al. 2016). Currently, $17 \%$ of the world's electricity generation is streamed from hydroelectric power (van Vliet et al. 2016). Like other developing countries, Sri Lanka too heavily depends on hydropower generation to fulfill its energy requirement (45-50\% of total electricity demand from 2010 to 2015) and highly favorable to generate hydropower in the future (Khaniya et al. 2018).

Run-of-the-river (ROR) hydropower plants worldwide are capable of generating about $200 \mathrm{GW}$ of hydroelectricity with special interest identified in developing countries in Asia and Africa (International Energy Agency 2016). However, interest in these projects has diminished since past studies have shown that global warming and climate variability may have severe impacts on available water resources for hydropower 
generation (Schär et al. 2004; Lehner et al. 2005; Hamududu and Killingtveit 2012).

Kao et al. (2015) studied on projected climatic changes in the future annual and regional hydropower generation with developed climate models and runoff-based assessment approach. Results showed that although there is a decrease in annual power generation, it appears to be marginable. Majone et al. (2016) have predicted that there will be an 2-6\% increase in water yield during 2040-2070 compared to later 20th century in the southeastern Alpine region due to lesser winter precipitation. Partial equilibrium bottomup optimization model (TIMES_PT) was used to assess the impact of climate change on power generation in Portugal's water resources by Teotónio et al. (2017). They derived that there will be a $41 \%$ decrement in hydropower by 2050 , while electricity prices will be increased by up to $7.2 \%$. In addition, they describe that the effect of climate change on generation of electricity based on non-thermal sources shows geographical variability due to forecasted changes in temperature and precipitation. However, Turner et al. (2017) showed that impact of climate variation and climate change would increase the hydropower generation in some parts of the world while decrease in some other parts of the world. Hamududu and Killingtveit (2012) have used simulations of regional patterns of runoff and related these to hydropower generation through geographical information systems (GIS) and showed that there will be fluctuations in power generation. Similarly, few other researchers have used different methods to predict the impact of climate change on hydropower generation. Global circulation models, which predict future climatic conditions using hypothetical scenarios, have been used by Aronica and Bonaccorso (2013), Shrestha et al. (2014) and Pilesjo and Al-Juboori (2016). Kabo-Bah et al. (2016) and Machina and Sharma (2017) have accessed the impacts of climate changes on hydropower generation with multi-year temperature and rainfall trend analysis. Khaniya et al. (2018) stated that this approach is easier and most suited given that the quality of data is at a satisfactory level. In addition, it states that this method depends on factors such as hydropower system installed, geographical coverage and availability of data for the analysis.

Sri Lanka being a tropical country is highly vulnerable to impacts of climate change and variability due to global warming and anthropogenic activities (Ministry of Mahaweli Development and Environment 2016). Over the past few decades, rainfall and temperature patterns in Sri Lanka have shown some variations and these have been resembled through the decrease in cumulative rainfall from southwest monsoon (SW) and northeast monsoon (NE), while an increment has observed in the intermediate season rainfall (Jayasundara and Shantha 2005; De Silva 2006; Iimi 2007; De Silva et al. 2007). According to Eriyagama et al. (2010), Sri Lanka's mean air temperature has increased by $0.016{ }^{\circ} \mathrm{C}$ per year and mean annual precipitation has decreased by $144 \mathrm{~mm}$ per year in between the periods of 1931-1960 and during the period 1961 to 1990. In addition, they have predicted that due to the change in volume and distribution of rainfall, there would be an increment of 0.9 to $4{ }^{\circ} \mathrm{C}$ of mean temperature by 2100 .

Although there is no exact quantitative justification, experts have suggested that there would be an increase in rainfall in wet zone, while a progressive decrease is expected in dry zone (Marambe et al. 2014). However, at present, no concerns have arisen regarding power deficit since most of the hydropower plants are located in wet zone (Ceylon Electricity Board 2014). Thus, there is no conclusive evidence on what will exactly happen in the future. Nevertheless, it is essential for Sri Lanka too to move on with world to study on climate change, depletion of water resources and power management for a better economy. However, studies on impact of climate change on hydropower production from river basins in Sri Lanka are rare in the literature. According to Jayasundara and Shantha (2005), there was a 39.12\% reduction in rainfall from 1902 to 2002 and they have forecasted that there would be a 16.6\% reduction by 2025 on Mahaweli river upper watershed area. Herath and Ratnayake (2004) showed that there is a significant decrease in rainfall over 60 rainfall stations from 1964 to 1993 period. However, they found that the intensity of rainfall was increasing. In addition, Ranatunge et al. (2003), Jayawardene et al. (2005), Wickramagamage (2016) and Karunathilaka et al. (2017) have put efforts in studying annual and seasonal rainfall trends in Sri Lanka. (Khaniya et al. 2018) presented some interesting rainfall trend analyses and linked them with the hydropower generation of a ROR hydropower plant. However, the literature does not provide any similar analyses in Sri Lanka for un-gauged catchments in some other parts of the world. Singh et al. (2001) and Kebede et al. (2011) have studied the impact of climate change on hydropower generation in un-gauged catchments using rainfall data from the surrounding rain gauges in Himalaya and Tana floodplains and Ethiopia, respectively.

Therefore, this paper presents the impact of climate change on hydropower generation in one of the un-gauged catchments in Sri Lanka, Erathna hydropower plant. This hydropower plant is an ROR hydropower plant, and it is becoming popular in Sri Lanka (Weerakoon and Rathnayake 2007). Mann-Kendall test and Sen's slope estimator test were used to analyze the trends, while Pearson's correlation coefficient was used to identify linear relationship between rainfall and power generation.

\section{Homogeneity tests for rainfall data series}

Trend analysis of climatic data totally depends on the quality of the data series which was used. Therefore, the reliability of the recorded climatic data is highly important. Thus many 
researches check the homogeneity of the climatic data series before it is used for any potential trend analysis (Alexandersson 1986; Kang and Yusof 2012; Alghazali and Alawadi 2014; Al-lami et al. 2015; Agha et al. 2017). Different tests are used to test the homogeneity of data series used for climatic studies. These tests help to validate that the same instrument was used to collect data within same time period at the same location (Alexandersson 1986; Alexandersson and Moberg 1997). Pettit's test, Buishand's test, Standard Normal Homogeneity Test (SNHT) and von Neumann's test are several homogeneity tests used (Buishand 1982; Alexandersson 1986; Alexandersson and Moberg 1997; Wijngaard et al. 2003; Haylock et al. 2008; Sahin and Cigizoglu 2010).

\section{Mann-Kendall test}

Mann-Kendall test is widely used trend analysis test in climatic data series. Mann (1945) first introduced this test to analyze the trends; however, it was implemented in 1975 (Kendall 1975). The nonparametric test was further improved with seasonality by Hirsch et al. (1982).

This test is commonly known as Mann-Kendall test and, as stated above, widely used to check temporal monotonic upward and downward trends of climate (Robson et al. 1998; De Luís et al. 2000; Cannarozzo et al. 2006; Kumar et al. 2006; Longobardi and Villani 2009; Ahmad et al. 2015; Machina and Sharma 2017; Sridhar and Raviraj 2017). Equation (1) gives the Mann-Kendall statistic $S$.

$S=\sum_{i=1}^{n-1} \sum_{j=i+1}^{n} \operatorname{sgn}\left(x_{j}-x_{i}\right)$

where S, $X_{j}$ and $X_{i}$ are Mann-Kendall's statistic S, time series and $n$ is the number of data points in the time series. The "sgn" sign function can be expressed as given in Eq. (2).

$\operatorname{sgn}\left(x_{j}-x_{i}\right)=\left\{\begin{array}{l}+1,>\left(x_{j}-x_{i}\right) \\ 0,=\left(x_{j}-x_{i}\right) \\ -1,<\left(x_{j}-x_{i}\right)\end{array}\right.$

The variance of the Mann-Kendall's test is given by Eq. (3)

$\operatorname{Var}(S)=\frac{n(n-1)(2 n+5)-\sum_{i=1}^{m} t_{i}(i)(i-1)(2 i+5)}{18}$

$Z_{\mathrm{c}}=\left\{\begin{array}{l}\frac{S-1}{\sqrt{\operatorname{Var}(S)}}, S>0 \\ 0, S=0 \\ \frac{S+1}{\sqrt{\operatorname{Var}(S)}}, S<0\end{array}\right.$

where $t_{i}$ is the number of ties up to sample $i$. Then, the Mann-Kendall's statistics Z is given by Eq. (4).
The $Z_{c}$ follows the standard normal distribution. A positive $Z_{c}$ value shows an upward trend, whereas a negative $Z_{c}$ gives a downward trend for the data period.

\section{Sen's slope estimator test}

Sen's slope is used to assess the magnitude of trend at a given time (Sen 1968) and used widely in rainfall trend analysis (Kumar et al. 2006; Ahmad et al. 2015; Sridhar and Raviraj 2017). Equation (5) is used to calculate slope for all data pairs.

$d_{\mathrm{k}}=\frac{X_{j}-X_{i}}{j-i}$

for $(1 \leq i<j \leq n)$, where $d_{\mathrm{k}}$ is the slope, $X_{j}$ and $X_{i}$ are data values at time $i$ and $j$, respectively, and $n$ is the number of data. The median of $n$ values of $d_{k}$ is given as Sen's slope estimator $\left(Q_{i}\right)$ and given by Eq. (6).

$Q_{i}= \begin{cases}d_{\frac{n+1}{2}}, & n \text { is odd } \\ \frac{1}{2}\left(d_{\frac{n}{2}}+d_{\frac{n+2}{2}}\right), & n \text { is even }\end{cases}$

Positive $Q_{i}$ values suggest that there is an increasing (upward) trend in climatic data series, while negative values suggest the opposite.

\section{Relationship between time series}

The Pearson's correlation coefficient is used to find the linear relationship between two data series. This is widely used for the statistical analysis of climatological and geophysical data (Puth et al. 2014; Wiedermann and Hagmann 2016; Jilin 2017; Ahmed and Kumar 2018). The linear correlation coefficient ( $r$ ) is given by Eq. (7).

$r=\frac{n \sum x y-\left(\sum x\right)\left(\sum y\right)}{\sqrt{n\left(\sum x^{2}\right)-\left(\sum x\right)^{2}} \sqrt{n\left(\sum y^{2}\right)-\left(\sum y\right)^{2}}}$

where $x=\left\{x_{1}, \ldots, x_{n}\right\}, y=\left\{y_{1}, \ldots, y_{n}\right\}$ are two sample data sets and $n$ is the number of pairs of data. The value of $r$ varies such that $-1 \leq r \leq+1$. where + and - signs indicate positive and negative linear correlations between $x$ and $y$, respectively. 


\section{Case study application-Erathna mini-hydropower plant}

Erathna mini-hydropower station is in Ratnapura district, Sri Lanka. Ratnapura district is in wet zone of the country. This area is highly vulnerable to frequent flooding due to higher rainfall volumes (Eriyagama et al. 2010; Karunathilaka et al. 2017). Rathnapura district receives a significant rainfall from SW monsoon from May to September (Punyawardena and Cherry 1999). However, district is famous for receiving rainfall throughout the year. The hydropower plant is a ROR type and utilizes the water flow from upper reaches of the Kuru Ganga. Figure 1 shows the catchment area of Erathna hydropower plant and its location within Sri Lanka.

Rainfall data for ten rain gauges were collected for 30 years (1988-2017) from the Meteorological Department, Sri Lanka, for the trend analysis. These rainfall gauges are shown in Fig. 1. They are Anhetigama estate (6.93 N, 80.37 E), Pussella S.P. (6.80 N, 80.35 E), Keragala $(6.78 \mathrm{~N}, 80.35 \mathrm{E})$, Maliboda $(6.88 \mathrm{~N}, 80.43 \mathrm{E})$, Galaboda estate $(6.70 \mathrm{~N}, 80.47 \mathrm{E})$, Alupolla group $(6.72 \mathrm{~N}$, 80.58 E), Hapugastenna estate (6.72 N, 80.52 E), Laxapana (6.90 N, 80.52 E), Maskeliya Hospital (6.83 N, 80.57 E) and Maussakelle (6.85 N, $80.55 \mathrm{E})$. Missing rainfall data due to instrument issues and recording issues were filled using normal ratio method. Then, the Pettitt's test,
SNHT, Buishand's test and von Neumann's test were used to check the homogeneity of data series. Mann-Kendall test and Sen's slope estimator test were applied on ten rainfall series on monthly, seasonal and annual basis to find any possible trends. The rainfall data series show that the area receives a significant rainfall throughout the year. This justifies the construction of Erathna ROR hydropower station. In addition, Pearson's correlation coefficient was computed between each rainfall series with the hydropower generation. This helps in linking the un-gauged catchment with the rainfall data from the surrounding rain gauges. The correlation coefficients were found for the data series from January 2010 to December 2017. The power generation data were obtained from Vallibel Power Erathna (2018) (http://www.vallibel-hydro.com/projects/ erathna-hydro-power.php).

\section{Results and discussion}

Figure 2 shows the annual rainfall variation over 30 years in the surrounding rain gauges of Erathna catchment. The figure clearly shows the zigzag pattern of the rainfall over the years. However, the annual rainfall in a particular rain gauge does not show significant sudden drops and rises other than in few cases (circled) for rain gauges in Keragala (years 1988 and 2004) and Maliboda (year 2010). These two gauging

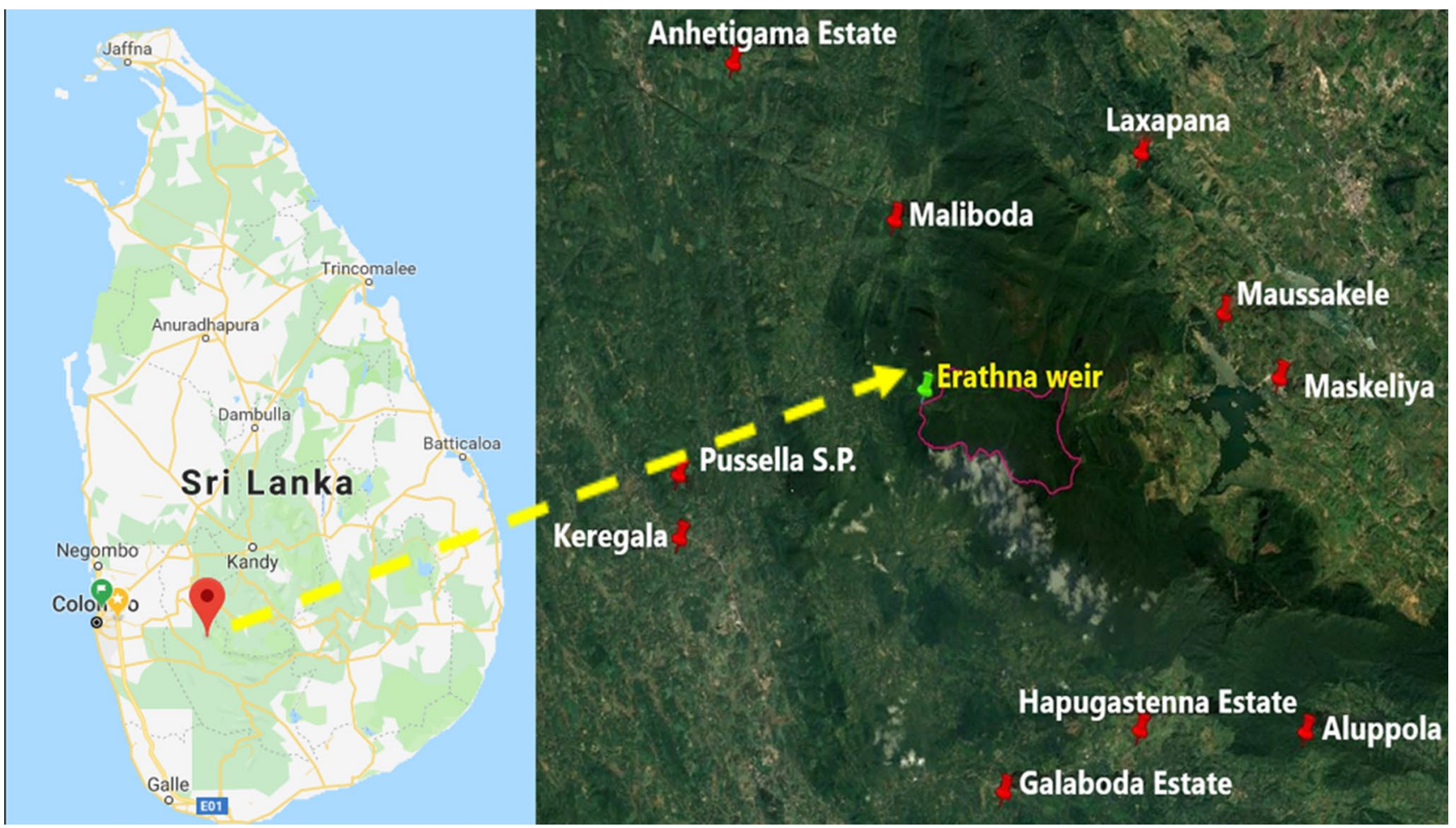

Fig. 1 Erathna catchment and its surrounding rain gauges 


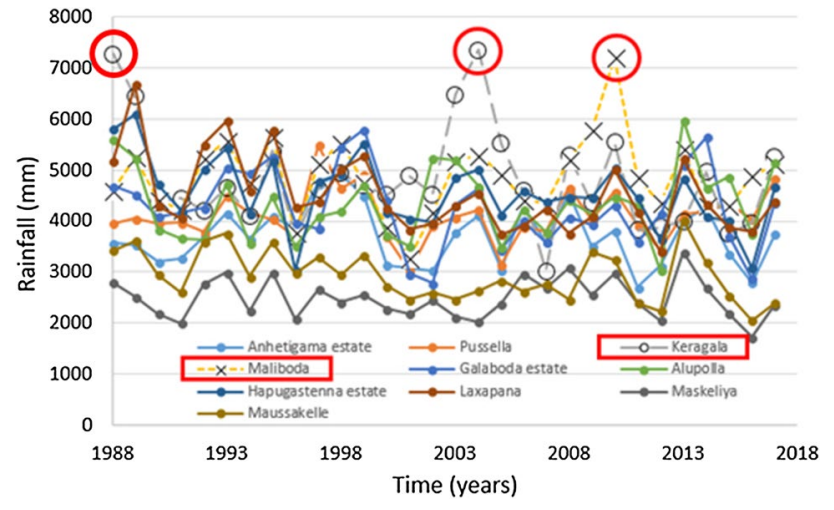

Fig. 2 Annual rainfall variation over 30 years

stations have extremely high annual rainfalls in those 2 years compared to the other corresponding rain gauging stations.

Homogeneous test results for the monthly rainfalls show that rainfall data are homogeneous. Therefore, the rainfall data can be used for the further analysis to find trends. The Mann-Kendall test results and Sen's slope estimator test results for annual rainfall for 30 years are tabulated in Table 1.

Among the rain gauges, only four rain gauges show significant trends in annual rainfall. Hapugastenna estate, Laxapana, Maskeliya and Maussakelle are these rain gauging stations. All other gauging stations do not show any potential trends in annual rainfall. Interestingly, the all four significant trends are negative trends. Therefore, this analysis shows that there is a decrease in the annual rainfall in the abovestated rain gauging stations. Sen's slope estimator gives these decreases in numerical values. For example, Laxapana rain gauge has a Sen's slope of -37.3 . This means the Laxapana area has a decrease of $37 \mathrm{~mm}$ of rainfall annually over the 30 years. This is a significant decrease in rainfall per year. However, this trend results are spread over a year

Table 1 Mann-Kendall test and Sen's slope estimator test results for annual rainfall

\begin{tabular}{lrll}
\hline Rain gauge station & \multicolumn{1}{c}{$Z_{\mathrm{c}}$} & $\begin{array}{l}\text { Significant (S)/ } \\
\text { insignificant (IS) }\end{array}$ & $\begin{array}{l}\text { Sen's slope } \\
(\mathrm{mm} / \mathrm{year})\end{array}$ \\
\hline Anhetigama estate & -0.500 & IS & 0 \\
Pussella & 0.714 & IS & 0 \\
Keragala & -0.892 & IS & 0 \\
Maliboda & 0.036 & IS & 0 \\
Galaboda estate & -1.178 & IS & 0 \\
Alupolla & 0.321 & IS & 0 \\
Hapugastenna estate & -2.243 & S & -40.4 \\
Laxapana & -2.676 & $\mathrm{~S}$ & -37.3 \\
Maskeliya & -2.248 & $\mathrm{~S}$ & -39.4 \\
Maussakelle & -2.962 & $\mathrm{~S}$ & -28.8 \\
\hline
\end{tabular}

span. Therefore, the trend analysis was carried for lower spans in time.

Nevertheless, an interesting feature can be observed for these four rain gauges which have negative trends. They are in the eastern side of the Erathna catchment. In addition, the trend analysis carried out for higher resolutions for the seasons and months shows the negative trend occurs in the SW monsoon of the year. This can be further looked at the higher resolution for the months, and interestingly, it was found that the month of July is the critical month to have the negative trends. However, Samanala mountain range (including the world-famous Adam's peak) lies in between the Erathna catchment and the concerned four rain gauges (Laxapana, Maussakelle, Maskeliya and Hapugastenna). The Samanala mountain range has an elevation around 2000-2250 m, while Laxapana, Maussakelle, Maskeliya and Hapugastenna have elevations around 1300-1400 m, 1200-1300 m, 1000-1100 m and 1150-1300 m, respectively. Therefore, these elevations clearly show that the SW monsoon is covered for the four rain gauges by Samanala mountain range. Figure 3 presents this scenario. Therefore, even if it is not a sound conclusion, it can be presented herein that the SW monsoon is getting weaker to break the Samanala mountain range due to ongoing climate variability. However, it is highly encouraged to complete a detailed study to obtain rich and sound conclusions on this matter. Nevertheless, it is very important to have such finding as the concerned area is having its maximum rainfall during the SW monsoon.

Table 2 shows the trend analysis results in the seasonal basis. As it was stated above, Sri Lanka experiences two major monsoon seasons and two intermediate seasons (SW and NE monsoons and 1st and 2nd intermediate seasons).

The table shows that there are several significant trends in some of the rain gauging stations but for SW monsoon and 1 st intermediate season. Interestingly, seasonal rainfall

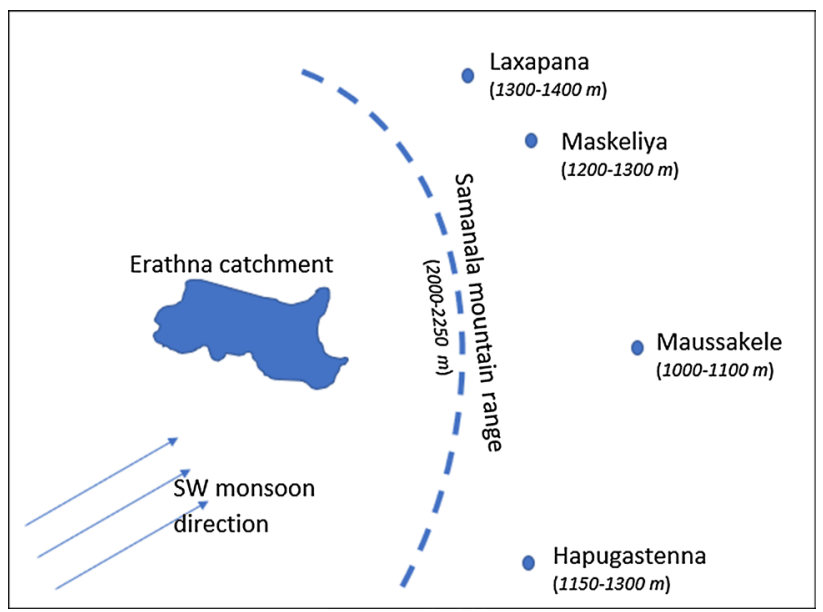

Fig. 3 Erathna catchment and Samanala mountain range

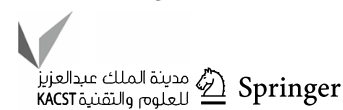


Table 2 Mann-Kendall test and Sen's slope estimator test results for seasonal rainfall

\begin{tabular}{|c|c|c|c|c|}
\hline Rain gauge station & Rainfall season & $Z_{\mathrm{c}}$ & $\begin{array}{l}\text { Significant (S)/insig- } \\
\text { nificant (IS) }\end{array}$ & $\begin{array}{l}\text { Sen's slope } \\
\text { (mm/season) }\end{array}$ \\
\hline \multirow[t]{4}{*}{ Anhetigama estate } & $\mathrm{NE}$ & 0.749 & IS & 0 \\
\hline & $1 \mathrm{st}$ & 0.928 & IS & 0 \\
\hline & SW & -1.035 & IS & 0 \\
\hline & 2nd & -0.785 & IS & 0 \\
\hline \multirow[t]{4}{*}{ Pussella } & $\mathrm{NE}$ & 1.178 & IS & 0 \\
\hline & $1 \mathrm{st}$ & 2.178 & $\mathrm{~S}$ & 8.6 \\
\hline & SW & -0.500 & IS & 0 \\
\hline & 2nd & -0.642 & IS & 0 \\
\hline \multirow[t]{4}{*}{ Keragala } & $\mathrm{NE}$ & 0.178 & IS & 0 \\
\hline & $1 \mathrm{st}$ & 0.923 & IS & 0 \\
\hline & SW & -0.928 & IS & 0 \\
\hline & 2nd & -1.178 & IS & 0 \\
\hline \multirow[t]{4}{*}{ Maliboda } & $\mathrm{NE}$ & 0.856 & IS & 0 \\
\hline & $1 \mathrm{st}$ & 0.714 & IS & 0 \\
\hline & SW & -0.393 & IS & 0 \\
\hline & 2nd & 0.107 & IS & 0 \\
\hline \multirow[t]{4}{*}{ Galaboda estate } & $\mathrm{NE}$ & 0.107 & IS & 0 \\
\hline & $1 \mathrm{st}$ & -0.036 & IS & 0 \\
\hline & SW & -1.142 & IS & 0 \\
\hline & 2 nd & -0.285 & IS & 0 \\
\hline \multirow[t]{4}{*}{ Alupolla estate } & $\mathrm{NE}$ & -0.178 & IS & 0 \\
\hline & $1 \mathrm{st}$ & 0.071 & IS & 0 \\
\hline & SW & 0.357 & IS & 0 \\
\hline & 2nd & 1.820 & IS & 0 \\
\hline \multirow[t]{4}{*}{ Hapugastenna estate } & $\mathrm{NE}$ & -0.178 & IS & 0 \\
\hline & $1 \mathrm{st}$ & -0.107 & IS & 0 \\
\hline & SW & -1.891 & IS & 0 \\
\hline & 2nd & -0.963 & IS & 0 \\
\hline \multirow[t]{4}{*}{ Laxapana } & NE & 0.321 & IS & 0 \\
\hline & $1 \mathrm{st}$ & -0.607 & IS & 0 \\
\hline & SW & -2.462 & $\mathrm{~S}$ & -36.6 \\
\hline & 2 nd & -0.464 & IS & 0 \\
\hline \multirow[t]{4}{*}{ Maskeliya } & $\mathrm{NE}$ & 1.356 & IS & 0 \\
\hline & $1 \mathrm{st}$ & 0.678 & IS & 0 \\
\hline & SW & -1.356 & IS & 0 \\
\hline & 2nd & 0.285 & IS & 0 \\
\hline \multirow[t]{4}{*}{ Maussakelle } & NE & 0.571 & IS & 0 \\
\hline & $1 \mathrm{st}$ & 0.607 & IS & 0 \\
\hline & SW & -3.211 & $\mathrm{~S}$ & -30.2 \\
\hline & 2nd & -1.213 & IS & 0 \\
\hline
\end{tabular}

$N E$ northeastern monsoon (December to February), $S W$ southwestern monsoon (May to September), 1st intermediate season (March to April) and 2nd intermediate season (October to November) shows one positive trend in 1st intermediate season for Pussella rain gauging station. This is around $8 \mathrm{~mm}$ increase per the season. (The season lasts for only 2 months, and therefore, the increase can be a considerable rainfall.) However, Laxapana and Maussakelle experienced significant rainfall decrease only in the southwestern monsoon period. Sen's slope estimator test shows the decreases are around
30-37 mm per the season. Interestingly, the wet zone of the Sri Lanka receives its maximum rainfall during the southwestern monsoon period, and therefore, the decrease in rainfall during the same period shows a concerned climatic variation. In addition, these climatic variations can adversely impact the water resources not only in this area but also in the downstream catchments. The rain-gauged areas 
are the primary catchment areas for few major rivers in Sri Lanka. Therefore, the results from the seasonal trend analysis illustrate the significance of the carried research work. In addition, the rainfall decrease can be clearly seen for the Laxapana and Maussakelle rain gauges for both annual and seasonal trend analyses. Furthermore, these decreased rainfall values are almost similar in the annual to seasonal. For example, Laxapana has a decrease of $37.3 \mathrm{~mm}$ per year in the annual trend analysis, while it has $36.6 \mathrm{~mm}$ in the SW monsoon season. However, other seasons do not show any significant trends in rainfall. Therefore, the SW monsoon trend is the only trend for the year and that also represents the annual base. The similar observation can also be seen in Maussakelle rain gauge too.

However, this observation cannot be seen in the Hapugastenna and Maskeliya rain gauging stations. They show negative trends in annual rainfall trend analysis but no significant trends in the seasonal rainfall trend analysis. Therefore, the trend analysis was carried to further smaller time spans in the monthly base. The results from the analysis are given in Table 3 . As it was expected and also shown in Table 1, Pussella rain gauge shows a positive trend in March. However, the rain gauge also shows a negative trend in July. The July negative trend is common for most of the other rain gauges. Therefore, the monthly rainfall trend analysis also shows the decrease in rainfall in southwestern monsoon period. In addition, Hapugastenna estate, Laxapana, Maskeliya and Maussakelle rain gauges show the usual decrease in rainfall similar to that shown in other time span trend analysis.

These trend analyses clearly show the impact of climate variability over the past 30 years from 1988 to 2017 . Therefore, the trend analyses prove the ongoing climate variability in the world. Identification of the impact of

Table 3 Sen's slope estimator test results for monthly rainfall

\begin{tabular}{|c|c|c|c|c|c|c|c|c|c|c|}
\hline \multirow[t]{2}{*}{ Month } & \multicolumn{10}{|c|}{ Sen's slope (mm/month) } \\
\hline & $\begin{array}{l}\text { Anheti- } \\
\text { gama } \\
\text { estate }\end{array}$ & Pussella & Keragala & Maliboda & $\begin{array}{l}\text { Galaboda } \\
\text { estate }\end{array}$ & Alupolla & $\begin{array}{l}\text { Hapugas- } \\
\text { tenna estate }\end{array}$ & Laxapana & Maskeliya & Maussakelle \\
\hline January & 0 & 0 & 0 & 0 & 0 & 0 & 0 & 0 & 0 & 0 \\
\hline February & 0 & 0 & 0 & 0 & 0 & 0 & 0 & 0 & 0 & 0 \\
\hline March & 0 & 5.3 & 0 & 0 & 0 & 0 & 0 & 0 & 0 & 0 \\
\hline April & 0 & 0 & 0 & 0 & 0 & 0 & 0 & 0 & 0 & 0 \\
\hline May & 0 & 0 & 0 & 0 & 0 & 0 & 0 & 0 & 0 & 0 \\
\hline June & 0 & 0 & 0 & 0 & 0 & 0 & 0 & 0 & 0 & 0 \\
\hline July & -6.0 & -6.0 & -8.0 & 0 & 0 & 0 & -8.8 & -14.0 & -6.5 & -10.3 \\
\hline August & 0 & 0 & 0 & 0 & 0 & 0 & 0 & 0 & 0 & 0 \\
\hline September & 0 & 0 & 0 & 0 & 0 & 0 & 0 & 0 & 0 & 0 \\
\hline October & 0 & 0 & 0 & 0 & 0 & 0 & 0 & 0 & 0 & 0 \\
\hline November & 0 & 0 & 0 & 0 & 0 & 0 & 0 & -7.1 & 0 & -4.0 \\
\hline December & 0 & 0 & 0 & 9.2 & 0 & 0 & 0 & 0 & 0 & 0 \\
\hline
\end{tabular}

Fig. 4 Hydropower generation of Erathna over the years

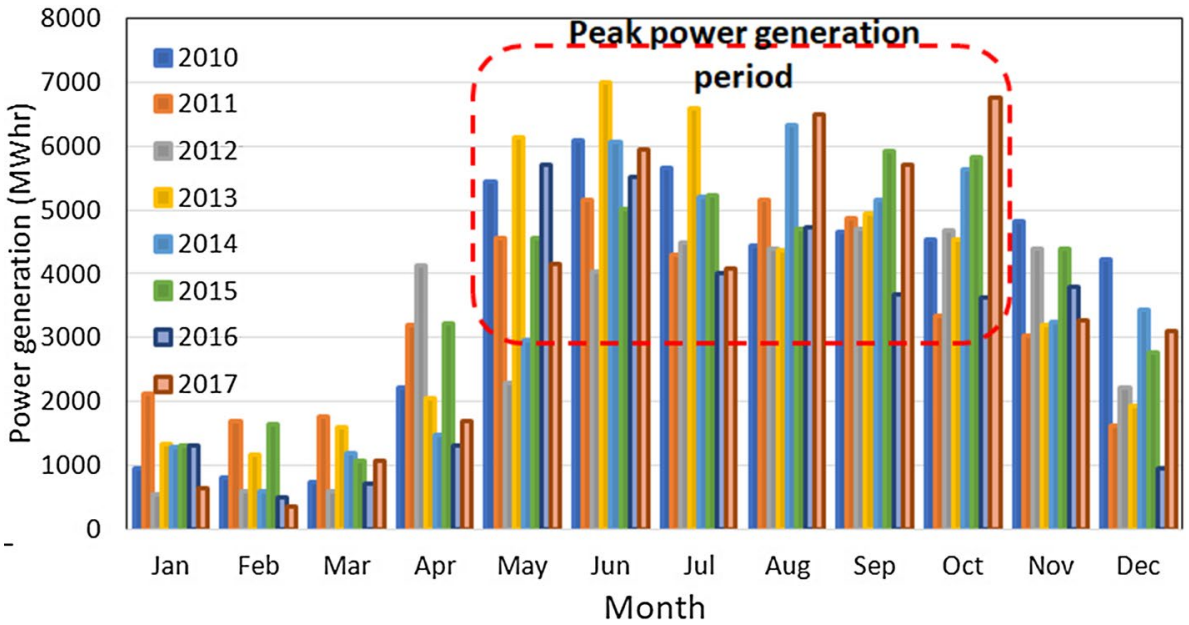


these climate variabilities on the available water resources would be interesting. Therefore, the following paragraphs present the impact of climate change on the hydropower generation in Erathna run-of-the-river hydropower plant.

Figure 4 demonstrates the generated hydropower from Erathna run-of-the-river hydropower plant since it was in operation (January 2010). The variations clearly reflect the available water resources in the catchment during the different months of the years. As it was expected, the power plant has lowered its power generation during the northeastern monsoon period. However, the power generation during the 1st intermediate season was gradually increased and reached the maximum during the southwestern monsoon period (May to September). Then, it has gradually decreased during the 2 nd intermediate season. The variation follows the amount of rainfall received by the catchment area during the four seasons. Interestingly, drops can be observed in the power generation during the month of July in all the years compared to preceding (June) and following (August) months. Therefore, it is highly important to investigate the relationship of power generation to the rainfall trends in the month of July. As it was stated above (Table 3), there is a considerable decrease in rainfall in July over the past 30 years. However, these rain gauges are outside catchment but closely surrounded the catchment. The power generation results suggest that there is a link to the rainfalls recorded in the surrounded rain gauges.

Figure 5 presents the annual power generation variation against the annual rainfall in the surrounding rain gauges during 2010 to 2017. Power generation variation shows couple of severe drops in years 2012 and 2016. The same observation can be seen in the rainfall variations too. Most of the rain gauges show the drops in 2012 and 2016. Similarly, power generation peaks can be seen in the years 2010, 2013, 2015 and 2017. The rainfalls during these years have significant increase compared to the preceding years. Therefore, the annual power generation variation and annual rainfall show a good agreement.

This relationship can further be seen in Fig. 6a, b. They present the monthly power generation variation against the monthly rainfall variation in years 2010 and 2017. They show clear monotonic relationship. Therefore, it can be concluded herein that the un-gauged catchment's water resources availability was successfully investigated using the catchment's surrounding rain gauges. However, to prove this scenario, a statistical analysis was carried out in order to find the Pearson's correlation coefficient between the rainfalls and the power generations. The results are presented in Table 4.
Fig. 5 Comparison of power generation against the annual rainfall
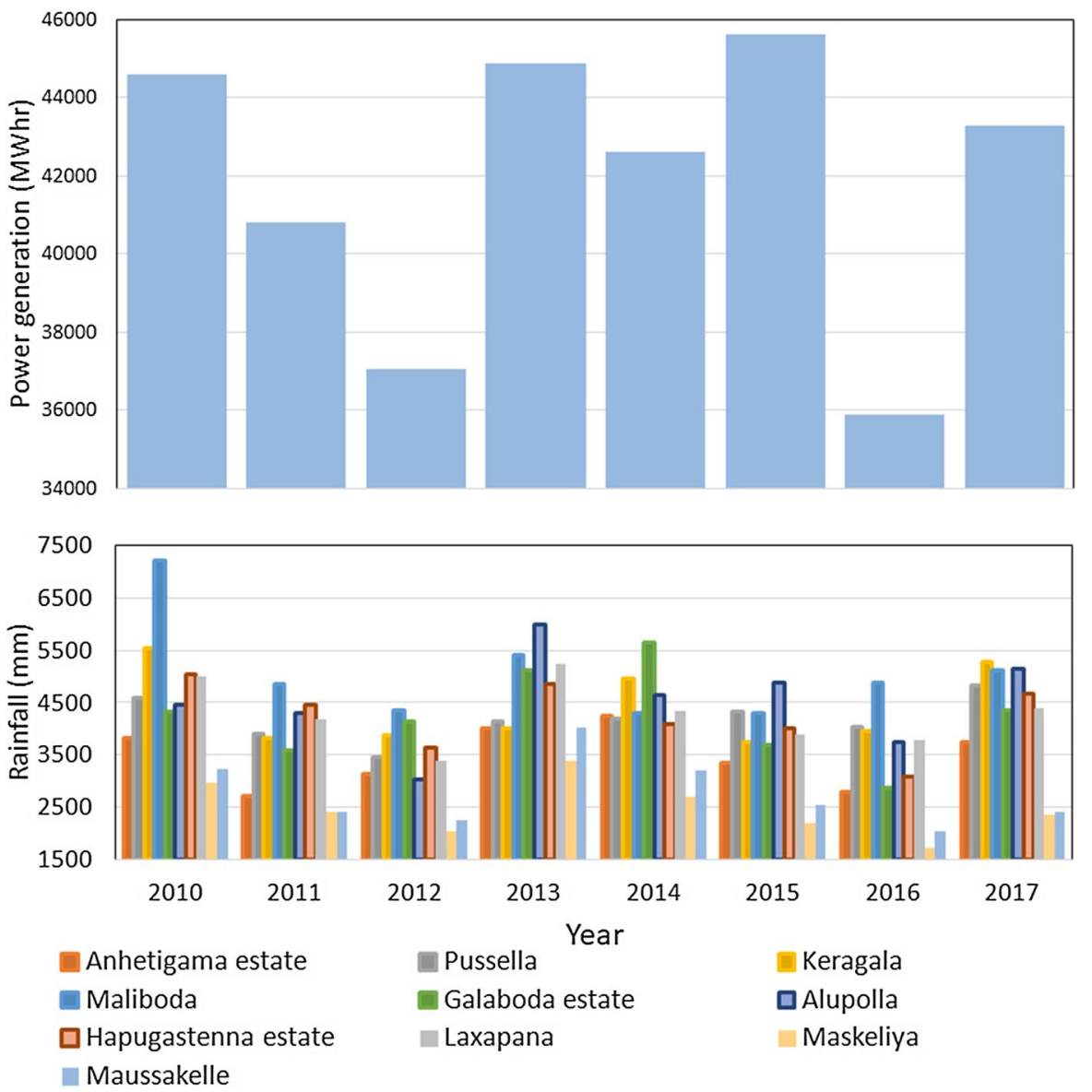

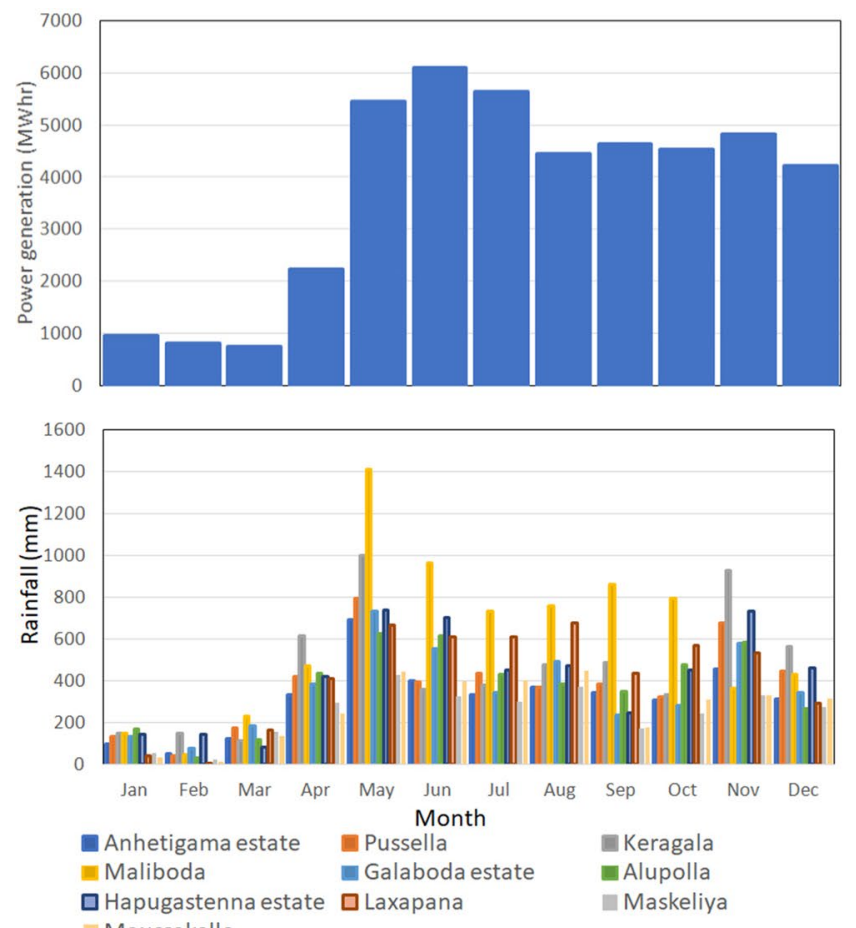

(a)
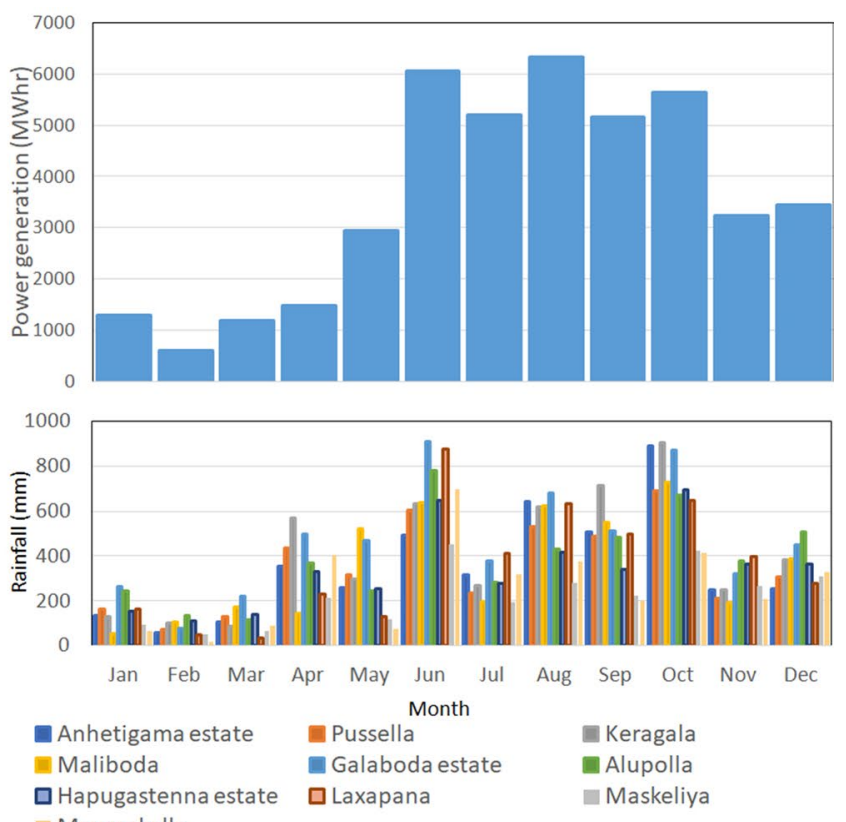

Maussakelle

(b)

Fig. 6 Comparison of monthly power generation against the monthly rainfall

Table 4 Pearson's correlation coefficients of rainfall and power generation time series

\begin{tabular}{ll}
\hline Rain gauge & $\begin{array}{l}\text { Pearson's corre- } \\
\text { lation coefficient }\end{array}$ \\
\hline Anhetigama estate & 0.58 \\
Pussella & 0.55 \\
Keragala & 0.58 \\
Maliboda & 0.70 \\
Galaboda estate & 0.70 \\
Alupolla & 0.69 \\
Hapugastenna estate & 0.70 \\
Laxapana & 0.80 \\
Maskeliya & 0.65 \\
Maussakelle & 0.69 \\
\hline
\end{tabular}

The coefficients are in between 0.55 and 0.8 which suggested that there is a clear link between the rainfall of the catchment's surrounding rain gauges and the power generation. Coefficient of 1.0 suggests that there is a total positive linear correlation between the two time series, whereas -1.0 suggests a total negative linear correlation. However, coefficient value of 0 suggests that there is no link between the time series. Therefore, the following table (Table 4) shows that there is a better correlation between the power generation with Laxapana, Maliboda, Galaboda estate, Hapugastenna estate and Maussakelle rainfalls. Out of these rain gauges, Laxapana, Hapugastenna estate and Maussakelle showed a clear reduction in rainfall for the southwestern monsoon. In addition, other rain gauges show some correlation between the power generation. Even though Anhetigama estate, Pussella and Keragala show a slightly lowered correlation coefficient $(0.58,0.55$ and 0.58 , respectively) compared to $0.7-0.8$, these rain gauges clearly showed a negative rainfall trend for the month of July, which is in the southwestern monsoon period.

Interestingly, the trend analysis found out that the rainfalls in better correlated rain gauges have negative trends in the major rainfall season to the area. Therefore, this finding is significant. There are clear evidences of rainfall decrease in this monsoon (southwestern) period, and the impact of that has clearly affected the hydropower generation in Erathna run-of-the-river hydropower station. Therefore, the ungauged catchment's water availability is in a risk during its major rainfall season.

\section{Conclusions}

The trend analyses clearly show that there are decreases in annual rainfalls of Hapugastenna estate, Laxapana, Maskeliya and Maussakelle. However, seasonal trend analyses support only Laxapana and Maussakelle rainfall decreases. These decreases are observed in the major rainfall season to

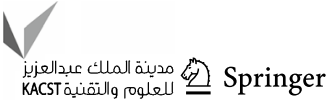


the area (southwestern monsoon). Therefore, results clearly show the impact of climate change/climate variability on the rainfall. In addition, results show a clear correlation between the rainfall and the power generation of the Erathna run-ofthe-river hydropower plant. Therefore, the impact of climate change/climate variability on the generated hydropower can be projected. Furthermore, results validate the rainfall data usage of catchment's surrounding rain gauges in such a study when the catchment is an un-gauged catchment. Therefore, the analysis can be handy for any future studies, where the catchment's rainfall data are unavailable. However, the Erathna run-of-the-river hydropower plant is merely a new one which has 8 years of power generation data. Therefore, the study should be further broadened with more power generation data in the future. Nevertheless, the presented research work clearly shows the impact of the ongoing climate variability on the received rainfall and water resources.

Open Access This article is distributed under the terms of the Creative Commons Attribution 4.0 International License (http://creativeco mmons.org/licenses/by/4.0/), which permits unrestricted use, distribution, and reproduction in any medium, provided you give appropriate credit to the original author(s) and the source, provide a link to the Creative Commons license, and indicate if changes were made.

\section{References}

Agha OMAM, Bağçacı SÇ, Şarlak N (2017) Homogeneity analysis of precipitation series in North Iraq. IOSR J Appl Geol Geophys 5(3):57-63. https://doi.org/10.9790/0990-0503025763

Ahmad I, Tang D, Wang T, Wang M, Wagan B (2015) Precipitation trends over time using Mann-Kendall and Spearman's rho tests in Swat river basin, Pakistan. Adv Meteorol 2015:1-15

Ahmed Z, Kumar S (2018) Pearson's correlation coefficient in the theory of networks: a comment 208701(2002):400085. http://arxiv .org/abs/1803.06937

Alexandersson H (1986) A homogeneity test applied to precipitation data. J Climatol 6(6):661-675. https://doi.org/10.1002/joc.3370060607

Alexandersson H, Moberg A (1997) Homogenization of Swedish temperature data, part I: homogeneity test for linear trends. Int J Climatol 17(1):25-34. https://doi.org/10.1002/(sici)10970088(199701)17:1\%3c25:aid-joc103\%3e3.0.co;2-j

Alghazali NOS, Alawadi DAH (2014) Testing the homogeneity of rainfall records for some stations in Iraq. Int J Civ Eng Technol 6308(3):294-300

Al-lami AM, Al-timimi YK, Al-salihi AM (2015) The homogeneity analysis of rainfall time series for selected meteorological stations in Iraq the homogeneity analysis of rainfall time series for selected meteorological stations the homogeneity analysis of rainfall time series for selected meteorolo (MAY 2014), pp 52-63

Aronica GT, Bonaccorso B (2013) Climate change effects on hydropower potential in the Alcantara River basin in Sicily (Italy). Earth Interactions. https://doi.org/10.1175/2012ei000508.1

Buishand TA (1982) Some methods for testing the homogeneity of rainfall records. J Hydrol 58(1-2):11-27. https://doi. org/10.1016/0022-1694(82)90066-x

Cannarozzo M, Noto LV, Viola F (2006) Spatial distribution of rainfall trends in Sicily (1921-2000). Phys Chem Earth 31(18):12011211. https://doi.org/10.1016/j.pce.2006.03.022
Ceylon Electricity Board (2014) Climate change risk assessment: moragolla hydropower plant. Democratic socialist republic of Sri Lanka: green power development and energy efficiency improvement investment program. [online] Colombo, pp 1-11. Available at: https://www.adb.org/sites/default/files/linked-docum ents/47037-003-sd-04.pdf. Accessed 23 Mar 2019

De Luís M, Raventós J, González-Hidalgo JC, Sánchez JR, Cortina J (2000) Spatial analysis of rainfall trends in the region of valencia (East Spain). Int J Climatol 20(12):1451-1469. https:// doi.org/10.1002/1097-0088(200010)20:12\%3c1451:aid-joc54 $7 \% 3$ e3.0.co;2-0

De Silva CS (2006) Impacts of climate change on water resources in Sri Lanka. In: Paper for the 32nd WEDC international conference, pp 289-295. https://doi.org/10.1061/(asce)he.19435584.0001436

De Silva CS, Weatherhead EK, Knox JW, Rodriguez-Diaz JA (2007) Predicting the impacts of climate change - A case study of paddy irrigation water requirements in Sri Lanka. Agric Water Manag 93(1-2):19-29. https://doi.org/10.1016/j.agwat.2007.06.003

Edenhofer O, Pichs-Madruga R, Sokona Y, Seyboth K, Matschoss P, Kadner S, Zwickel T, Eickemeier P, Hansen G, Schlomer S, von Stechow C (2011) IPCC, 2011: summary for policymakers. In: IPCC special report on renewable energy sources and climate change mitigation, Cambridge University Press, Cambridge. https ://doi.org/10.5860/choice.49-6309

Eriyagama N, Smakhtin V, Chanrapala L, Fernando K (2010) Impacts of climate change on water resources and agriculture in Sri Lanka: a review and preliminary vulnerability mapping, International Water Management Institute. https://doi.org/10.1007/s1339 8-014-0173-7.2

Hamududu B, Killingtveit A (2012) Assessing climate change impacts on global hydropower. Energies 5(2):305-322. https://doi. org/10.3390/en5020305

Haylock MR, Hofstra N, Klein Tank AMG, Klok EJ, Jones PD, New M (2008) A European daily high-resolution gridded data set of surface temperature and precipitation for 1950-2006. J Geophys Res Atmos. https://doi.org/10.1029/2008jd010201

Herath S, Ratnayake U (2004) Monitoring rainfall trends to predict adverse impacts - a case study from Sri Lanka (1964-1993). Global Environ Change 14:71-79. https://doi.org/10.1016/j.gloen vcha.2003.11.009

Hirsch R, Slack J, Smith R (1982) Techniques of trend analysis for monthly water quality data. Water Resour Res 18(1):107-121

Iimi A (2007) Estimating global climate change impacts on hydropower projects : applications in India, Sri Lanka and Vietnam, (September), pp 1-38

International Energy Agency (2016) Medium-Term Market Report 2016. https://doi.org/10.1787/9789264188471-en

Jayasundara JMSB, Shantha WWA (2005) Study on changes of rainfall in the Mahaweli upper watershed in Sri Lanka due to climatic changes and develop a correction model for global warming. In: International Symposium on the Stabilisation of Greenhouse Gas Concentrations, p. 6. http://stabilisation.metoffice.com/posters/ Shantha_WWA.pdf

Jayawardene H, Sonnadara D, Jayewardene D (2005) Trends of rainfall in Sri Lanka over the last century. Sri Lankan J Phys 6:7. https:// doi.org/10.4038/sljp.v6i0.197

Jilin CQ (2017) Joint inversion of geophysical data based on local pearson correlation constraints', June 2017, pp 12-15. https://doi. org/10.3997/2214-4609.201700790

Kabo-Bah AT, Diji CJ, Nokoe K, Mulugetta Y, Obeng-Ofori D, Akpoti K (2016) Multiyear rainfall and temperature trends in the Volta river basin and their potential impact on hydropower generation in Ghana. Climate 4(4):49. https://doi.org/10.3390/cli4040049

Kang HM, Yusof F (2012) Homogeneity Tests on Daily Rainfall Series in Peninsular Malaysia. Int. J. Contemp. Math. Scie. 7(1):9-22 
Kao SC, Sale MJ, Ashfaq M, Martinez RU, Kaiser DP, Wei Y, Diffenbaugh NS (2015) Projecting changes in annual hydropower generation using regional runoff data: an assessment of the United States federal hydropower plants. Energy 80(865):239-250. https ://doi.org/10.1016/j.energy.2014.11.066

Karunathilaka KLAA, Dabare HKV, Nandalal KDW (2017) Changes in rainfall in Sri Lanka during 1966-2015. Eng J Inst Eng Sri Lanka 50(2):39. https://doi.org/10.4038/engineer.v50i2.7251

Kebede S, Admasu G, Travi Y (2011) Estimating ungauged catchment flows from lake Tana floodplains, Ethiopia: an isotope hydrological approach. Isot Environ Health Stud 47(1):71-86. https://doi. org/10.1080/10256016.2011.556724

Kendall M (1975) Rank correlation methods, 4th edn. Charles Griffin \& Co., Ltd., London

Khaniya B, Priyantha HG, Baduge N, Azamathulla HM, Rathnayake U (2018) Impact of climate variability on hydropower generation: a case study from Sri Lanka. ISH J Hydraul Eng. https://doi. org/10.1080/097150https://doi.org/10.2018.1485516

Kumar KR, Sahai AK, Kumar KK, Patwardhan SK, Mishra PK, Revadekar JV, Kamala K, Pant GB (2006) High-resolution climate change scenarios for India for the 21st century. Curr Sci 9(3):334-345

Lehner B, Czisch G, Vassolo S (2005) The impact of global change on the hydropower potential of Europe: a model-based analysis. Energy Policy 33(7):839-855. https://doi.org/10.1016/j.enpol 2003.10.018

Longobardi A, Villani P (2009) Trend analysis of annual and seasonal rainfall time series in the Mediterranean area. Int J Climatol. https ://doi.org/10.1002/joc.2001

Machina MB, Sharma S (2017) Assessment of climate change impact on hydropower generation: a case study of Nigeria. Int J Eng Technol Sci Res 4(8):753-762

Majone B, Francesca V, Deidda R, Bellin A (2016) Impact of climate change and water use policies on hydropower potential in the south-eastern Alpine region. Sci Total Environ 543:965-980. https://doi.org/10.1016/j.scitotenv.2015.05.009

Mann H (1945) Nonparametric tests against trend. Econometrica 13(3):245-259

Marambe B, Silva P, Weerahewa J, Pushpakumara G, Punyawardena R, Pallawala R (2014) Enabling policies for agricultural adaptations to climate change in Sri Lanka. In: Leal W (ed) Handbook of climate change adaptation. Springer, Berlin. https://doi. org/10.1007/978-3-642-40455-9_108-2

Ministry of Mahaweli Development and Environment (2016) National adaptation plan for climate change in Sri Lanka 2016-2025. J and D Publishing House, ISBN 978-955-0033-98-0, Sri Lanka

Pilesjo P, Al-Juboori SS (2016) Modelling the effects of climate change on hydroelectric power in Dokan, Iraq. Int J Energy Power Eng 5(2):1-7. https://doi.org/10.11648/j.ijepe.s.2016050201.12

Punyawardena BVR, Cherry NJ (1999) Assessment of the predictability of seasonal rainfall in Rathnapura using the southern oscillation and its two extremes. J Natl Sci Found Sri Lanka 27(3):187-195

Puth MT, Neuhäuser M, Ruxton GD (2014) Effective use of Pearson's product-moment correlation coefficient. Anim Behav 93:183-189. https://doi.org/10.1016/j.anbehav.2014.05.003

Ranatunge E, Malmgren BA, Hayashi Y, Mikami T, Morishima W, Yokozawa MY, Nishimori M (2003) Changes in the southwest monsoon mean daily rainfall intensity in Sri Lanka: relationship to the El Niño-southern oscillation. Palaeogeogr Palaeoclimatol Palaeoecol 197(1-2):1-14. https://doi.org/10.1016/s0031-0182(03)00383-3

Robson AJ, Jones TK, Reed DW, Bayliss AC (1998) A study of national trend and variation in UK floods. Int J Climatol 18(2):165-182. https://doi.org/10.1002/(sici)1097-0088(199802)18:2\%3c165:aidjoc $230 \% 3 \mathrm{e} 3.0 . \mathrm{co} ; 2-\% 23$

Sahin S, Cigizoglu HK (2010) Homogeneity analysis of Turkish meteorological data set. Hydrol Process 24(8):981-992. https://doi. org/10.1002/hyp.7534
Schär C, Vidale PL, Lüthi D, Frei C, Häberli C, Liniger MA, Appenzeller C (2004) The role of increasing temperature variability in European summer. Nature 427(January):332-336. https://doi. org/10.1038/nature02230.1

Sen PK (1968) Estimates of the regression coefficient based on Kendall's Tau. J Am Stat Assoc 63(324):1379-1389. https://doi. org/10.1080/01621459.1968.10480934

Shrestha S, Khatiwada M, Babel MS, Parajuli K (2014) Impact of climate change on river flow and hydropower production in Kulekhani Hydropower Project of Nepal. Environ Process 1(3):231250. https://doi.org/10.1007/s40710-014-0020-z.de

Singh RD, Mishra SK, Chowdhary H (2001) Regional flow-duration models for large number of ungauged Himalayan catchments for planning. J Hydrol Eng 6(4):310-316

Smith R (2018) Three countries are leading the renewable energy revolution, World Economic Forum. https://www.weforum.org/ agenda/2018/02/countries-behind-global-renewable-energy-growt h/. Accessed 18 June 2018

Sridhar S, Raviraj A (2017) Statistical trend analysis of rainfall in Amaravathi river basin using Mann-Kendall test. Curr World Environ 12(1):89-96. https://doi.org/10.12944/cwe.12.1.11

Tarroja B, AghaKouchak A, Samuelsen S (2016) Quantifying climate change impacts on hydropower generation and implications on electric grid greenhouse gas emissions and operation. Energy 111:295-305. https://doi.org/10.1016/j.energy.2016.05.131.teoto nio

Teotónio C, Fortes P, Roebeling P, Rodriguez M, Robaina-Alves M (2017) Assessing the impacts of climate change on hydropower generation and the power sector in Portugal: a partial equilibrium approach. Renew Sustain Energy Rev 74:788-799. https://doi. org/10.1016/j.rser.2017.03.002.turner

Turner SWD, Hejazi M, Kim SH, Clarke L, Edmonds J (2017) Climate impacts on hydropower and consequences for global electricity supply investment needs. Energy 141:2081-2090. https://doi. org/10.1016/j.energy.2017.11.089

Vallibel Power Erathna (2018) Erathna mini hydro power plant. http:// www.vallibel-hydro.com/projects/erathna-hydro-power.php.van

Vliet MTH, Wilberg D, Leduc S, Riahi K (2016) Power-generation system vulnerability and adaptation to changes in climate and water resources. Nat Climate Change 6(4):375-380. https://doi. org/10.1038/nclimate2903

Weerakoon SB, Rathnayake US (2007) Effect of the entrance zone on the trapping efficiency of Desilting tanks in run-of-river hydropower plants. In: International conference on small hydropower, October, pp 1-6

Wickramagamage P (2016) Spatial and temporal variation of rainfall trends of Sri Lanka. Theor Appl Climatol 125(3-4):427-438. https://doi.org/10.1007/s00704-015-1492-0

Wiedermann W, Hagmann M (2016) Asymmetric properties of the Pearson correlation coefficient: correlation as the negative association between linear regression residuals. Commun Stat Theory Methods 45(21):6263-6283. https://doi.org/10.1080/03610 926.2014.960582

Wijngaard JB, Klein Tank AMG, Können GP (2003) Homogeneity of 20th century European daily temperature and precipitation series. Int J Climatol 23(6):679-692. https://doi.org/10.1002/joc.906

Williams JH, DeBenedictis A, Ghanadan R, Mahone A, Moore J, Morrow WR III, Price S, Torn MS (2012) The technology path to deep greenhouse gas emissions cuts by 2050: the pivotal role of electricity. Science 335:53-59. https://doi.org/10.1126/scien ce. 1208365

Publisher's Note Springer Nature remains neutral with regard to jurisdictional claims in published maps and institutional affiliations. 